\title{
New Materials of Leptostrobus myeongamensis Kim (Czekanowskiales) from the Upper Triassic Amisan Formation of Nampo Group in Korea
}

\author{
Jong-Heon Kim* \\ Department of Earth Science Education, Kongju National University, Chungnam 314-701, Korea
}

\begin{abstract}
Some materials belonging to the Leptostrobus myeongamensis Kim were found in the Upper Triassic Amisan Formation, Nampo Group, Korea. This species is closely associated with the foliage of Czekanowskia ex gr. rigida Heer. Although none of Leptostrobus myeongamensis Kim has been found in organic connection with Czekanowskia leaves, it is considered that they belong to the same taxa based on their common occurrence. The occurrence of Leptostrobus myeongamensis Kim from the Late Triassic floras of Korea is one of the oldest records in the Mesozoic floras found in the world.
\end{abstract}

Keywords: Leptostrobus myeongamensis, Czekanowskia ex gr. rigida, Late Triassic, Amisan Formation, Czekanowskiales

\section{Introduction}

The genus Leptostrobus belonging to Czekanowskiales is characterized by a slender cone axis bearing rather distant fertile cones above and small scale leaves at the base. This genus has been known as a female reproductive organ of Czekanowskia Heer (Harris, 1951). The genus Leptostrobus was first established by Heer (1876) from the Middle Jurassic in Ust-Balei and Kajamundung of the Amurland region, Siberia. It is now mostly recorded from the Mesozoic strata in the northern Hemisphere (e.g., Harris, 1951; Vakhrameev, 1964; Samylina, 1967; Krassilov, 1968, 1970; Harris and Miller, 1974; Kimura and Tsujii, 1984; Kim et al., 2002; Miao, 2003; Liu et al., 2006) but rarely in the southern Hemisphere (Jones and De Jersey, 1947; Clifford and Camilleri, 1998).

To date twenty species of Leptostrobus have been identified and described from the Mesozoic strata of the world (Kim et al., 2002). Among them, most species of Leptostrobus have been known from the Lower Jurassic to Lower Cretaceous strata of the world. In the Late Triassic, reproductive organ fossils belonging to Leptostrobus are very rare, and only five species of them have been identified from the Upper
Triassic strata of the world (Oishi and Takahashi, 1936; Oishi, 1940; Jones and De Jersey, 1947; Wang and Wang, 1984, Clifford and Camilleri, 1998; Kim et al., 2002; Liu et al., 2006).

In Korea, the existence of Czekanowskiales was first recognized, when Kawasaki (1939) described Czekanowskia setacea Heer from the Bansong Group in the Yeongweol area, Gangweon-do. On that date, Kawasaki (1939) regarded it as belonging to a genus of Ginkgoales. However, Kawasaki's Czekanowskia setacea Heer has been transferred to $C$. sp. belonging to Czekanowskiales by Kimura and Kim (1984a). The genus Leptostrobus was first described in Korea as $L$. myeongamensis Kim from the Late Triassic Amisan Formation of Nampo Group distributed in the Chungnam Basin (Kim et al., 2002).

Recently, although incomplete, one cone axis and two cone bases of reproductive organs belonging to Leptostrobus with many other fossil plants were collected from the Amisan Formation at the inkstone quarry in the Myeongam area, Dongdae-dong, Boryeong-city, Chungcheongnam-do. In this study, this author described the reproductive organs of Leptostrobus based on the new materials and explored its paleogeographic significance.

\footnotetext{
*Corresponding author: jongheon@kongju.ac.kr

Tel: 82-41-850-8295

Fax: 82-41-850-8299
} 


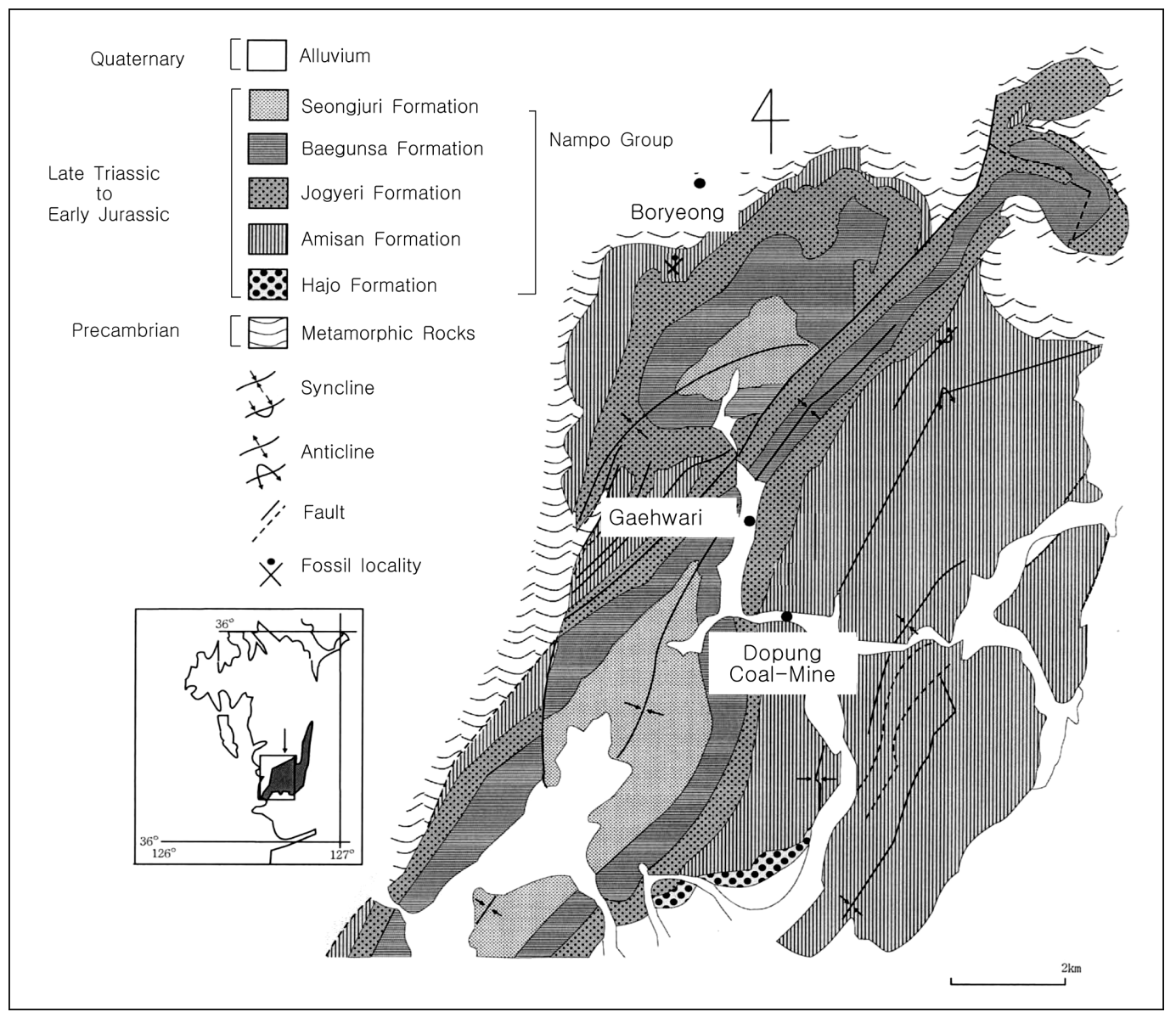

Fig. 1. Geologic map of the study area (partly modified from Choi et al., 1986) and fossil locality.

\section{Stratigraphy}

The Nampo Group is distributed in the Chungnam Sedimentary Basin of the southwestern part of Chungcheongnam-do, Korea. Shimamura (1931) first surveyed geological investigation in the Chungnam Sedimentary Basin, and then some geological studies were carried out by several geologists (e.g., Reedman and Um, 1975; Suh et al., 1980). According to Suh et al. (1980), the Nampo Group is subdivided into five formations, i.e., the Hajo, Amisan, Jogyeri, Baegunsa and Seongjuri Formations in an ascending order. Depositional environment of the Nampo Group has been considered to be an alluvial fan, fluvial plain, and lake environment (Choi et al., 1986, 1988). The fossil locality is the Myeongam area (N 36 28'02", E $\left.127^{\circ} 08^{\prime} 40^{\prime \prime}\right)$ shown in Fig. 1. The geologic age of the Amisan Formation based on the fossil plants and conchostracans has been considered to be Late Triassic (Kimura and Kim, 1984a, 1984b; Kobayashi, 1975; Kim and Kimura, 1988, 1989; Kim, 1993, 2001).

\section{Systematic Description}

Order Czekanowskiales

Genus Leptostrobus Heer 1876 emended Harris 1951

Type species Leptostrobus laxiflora Heer 1876

Leptostrobus myeongamensis Kim 2002

Figs. 2A-C

Leptostrobus myeongamensis Kim: 2002, text figs. 34, Figs. 5-6. 


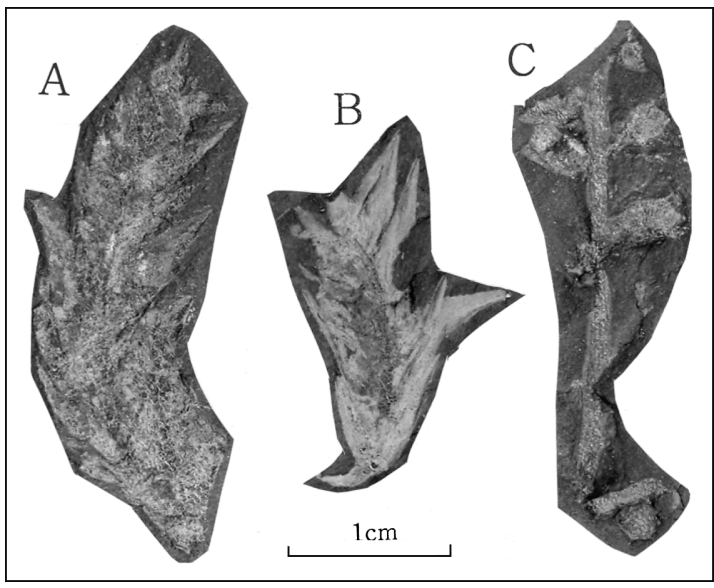

Fig. 2. Cone axis and cone base of Leptostrobus myeongamensis Kim. A, B; A part of cone base, covered with compact scale leaves. C; A upper part of cone axis bearing lateral capsules, all scale leaves are detached.

Material: KNU-2009-0001, 0002, 0003. The specimens herein examined will be deposited at the Department of Earth Science, Education of College., Gongju National University. The specimens are associatied with Czekanowskia ex gr. rigida Heer, Neocalamites carrerei (Zeiller), Baiera cf. furcata Braun, and Sphenobaiera cf. spectabilis (Nathorst).

Distribution and occurrence: This species is only known from the Amisan Formation and very rare in occurrence.

Description: A single cone axis and two cone bases were obtained from the Amisan Formation, but they are all broken and preserved as impression.

Cone axis: A fragment of cone axis is probably middle parts of cone axes (Fig. 2C). Cone axes is slender and unbranched, $3 \mathrm{~cm}$ in length and $1-2 \mathrm{~mm}$ in width, bearing loose spirally disposed capsules at intervals of $5 \mathrm{~mm}$. Capsule is poorly preserved, obovate or rounded in shape and sessile, $5-6 \mathrm{~mm}$ in length and 3-4 $\mathrm{mm}$ in width. The structure of capsule is uncertain and seeds and two valves of capsule are not recognized

Cone base: Two broken small fragments of cone bases were obtained. One is $3 \mathrm{~cm}$ in length and $1 \mathrm{~cm}$ in width. The axis is covered with compact scale leaves (Fig. 2A), but it's exact phyllotaxy is unknown.
The scale leaf is lanceolate in shape with acutely pointed apex, 6-7 $\mathrm{mm}$ in length and $2 \mathrm{~mm}$ in the widest basal part. Another cone base (Fig. 2B) is 2.5 $\mathrm{cm}$ in length and $1.5 \mathrm{~cm}$ in width, covered with small scale leaves. The scale leaves are similar in size and form to those of Fig. $2 \mathrm{~A}$ as mentioned above. Although their size differs, the present two fragments of cone base are considered to be the same species because of the similarity of their scale leaves in size and form.

\section{Discussion}

The morphological features of the present cone axis and cone base are nearly identical in all respects to Leptostrobus myeongamensis Kim originally described by Kim et al. (2002) from the same locality except for the absence of subtending scale leaves on the cone axis. According to Kim et al. (2002), the cone axis of L. myeongamensis $\mathrm{Kim}$ is characterized by the presence of capsules in loose spiral, each capsule consisting of a rounded capsule and its subtending a scale leaf. Among twenty species of Leptostrobus including 15 species reviewed by Liu et al. (2006), $L$. myeongamensis Kim is unique in the presence of scale leaves on the cone axis. The presence of scale leaves on the cone axis was already mentioned by Krassilov (1968, 1970) and Harris and Miller (1974). According to Harris and Miller (1974), seed capsule is wedgeshaped or rounded, almost sessile on cone axis, or shortly stalked and stalk sometimes with a few scale leaves. However, most species of Leptostrobus did not associate with scale leaves as shown in the present material. Judging from this fact, scale leaves on the cone axis appears to be caducous. The same feature is also shown in L. myeongamensis Kim (Kim et al., 2002, Fig. 5c).

Harris and Miller (1974) also mentioned that each capsule has two valves, each valve bearing small elongated seeds on its inner face. In the present cones, any valves and seeds on capsules are not recognized. It means that the present cone axis is considered to be immature or abortive. When the cones are fully 


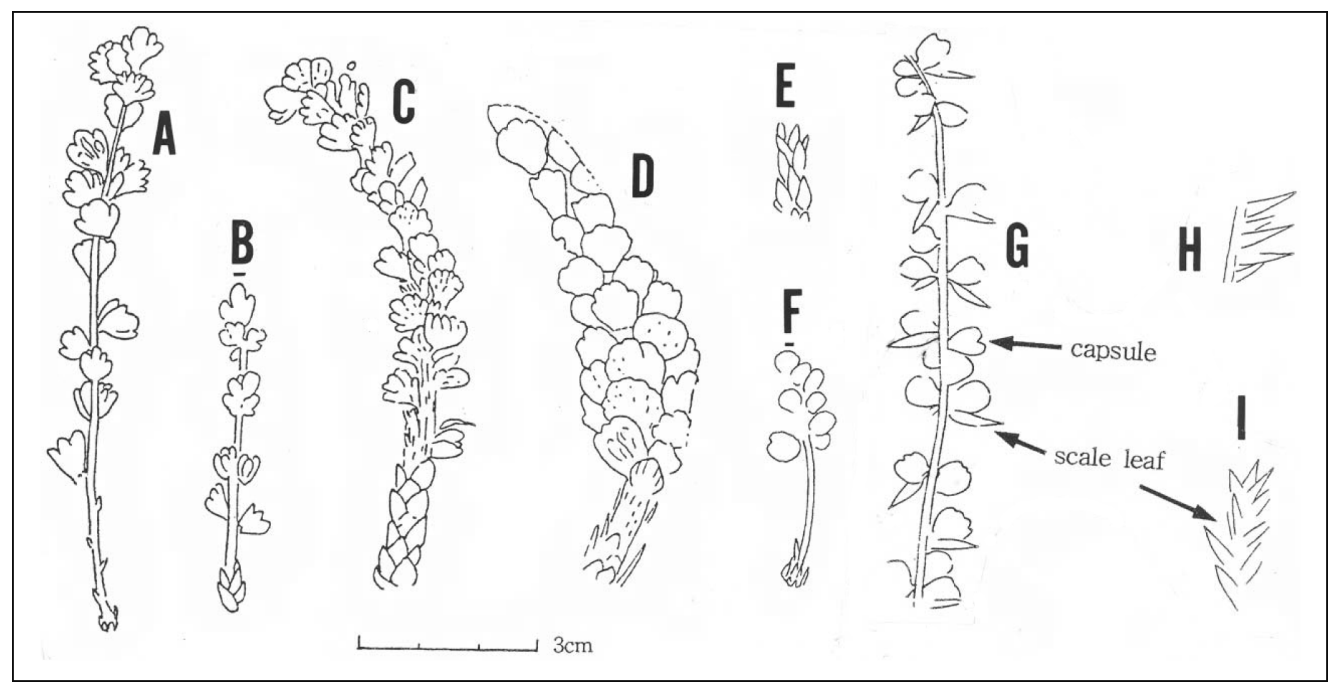

Fig 3. Comparison of Leptostrobus myeongamensis Kim with four species of Leptostrobus with basal scale leaves. A, B; Leptostrobus laxiflora Heer(1876, pl. 13, Fig. 10A;1880, pl. 7, Fig. 4). C, D; Leptostrobus crassipes Heer(1876, pl. 13, Fig. 15; 1880, pl. 8, Fig. 2). E; Leptostrobus sphaericus Wang(Wang and Wang, 1984, pl. 154, Fig. 7). F; Leptostrobus cancer Harris (Harris and Miller, 1974, pl. 7, Fig. 4). G-I; Leptostrobus myeongamensis Kim (Kim et al., 2002, Figs. 3, 4)

grown, scale leaves appear to be easy to shed from ripe capsules or during the fossilization.

Apart from the presence of scale leaves on cone axis, most species of Leptostrobus did not associate with cone base bearing compact scale leaves. Only four species are known to have the scale leaves on the cone base like those of the L. myeongamensis Kim (Fig. 3). They are Leptostrobus laxiflora Heer, L. crassipes Heer (1876, 1880), L. cancer Harris (in Harris et al., 1974), L. sphaericus Wang (Wang and Wang, 1984; Liu et al., 2006). They are easily distinguished in shape and size of scale leaves from Leptostrobus myeongamensis Kim (Kim et al., 2002).

The genus Leptostrobus has been associated with Czekanowskia leaves as fully discussed by Harris and Miller (1974). This association has been based on their common occurrence in the same horizon and the similarity of the cuticles (Harris and Miller, 1974; Taylor and Taylor, 1993; Taylor et al., 2010). Besides the Czekanowskia leaves, species of the Leptostrobus has been associated with foliages of Sphenobaiera, Phoenicopsis and Solenites (Taylor et al., 2010). However, the characters of Czekanowskia leaves are easily distinguished from those assigned to Neocalamites,
Baiera and Sphenobaiera. In Korea, Leptostrobus myeongamensis Kim has been closely associated with a foliage of Czekanowskia ex gr. rigida Heer, but none of them has been found in organic connection with Czekanowskia leaves. However, their common occurrence would indicate that they belong to the same taxa. Apart from the Czekanowskia leaves from the Nampo Group, the following species are described from the same locality: Neocalamites carrerei (Zeiller), Dictyophyllum exile (Braun), Baiera cf. furcata (Lindley et Hutton), Sphenobaiera cf. spectabilis (Nathorst), Phoenicopsis ex gr. angustifolia Heer and Podozamites ex gr. distans (Presl) (Kim, 1993, 2001; Kim and Roh, 2008).

Taylor and Taylor (1993) mentioned that Czekanowskiales extends from the Jurassic into the Early Cretaceous. However, many species belonging to Czekanowskiales have been described from the Late Triassic to Early Cretaceous floras in the northern Hemisphere (Vakhrameev, 1964; Krassilov, 1968; Kimura and Tsujii, 1984). Therefore, the geologic range of Czekanowskiales is to be extended back from the Late Triassic to the Early Cretaceous (Ash, 1994). Judging from the Mesozoic records of Czekanow- 
skiales, it seems to have reached its maximum development during the Early Jurassic and Early Cretaceous and, it shows world-wide distribution in the northern Hemisphere. Krassilov (1968) suggested that the geologic and geographic distribution of the Czekanowskiales was limited to the northern Hemisphere. He also mentioned that the Czekanowskiales acted as a dominant group from the Late Triassic to the Early Cretaceous and even persisted into the Cenomanian and Turonian in the Siberian Paleofloral Province (Krassilov, 1968). In the northern Hemisphere, high abundance and diversity of the Czekanowskiales can be taken as a good indicator of northern type, because only a minority of the Czekanowskiales are adapted to the warm climate in the southern Hemisphere (Jones and De Jersey, 1947; Clifford and Camilleri, 1998).

The Czekanowskiales is not a dominant group in the Late Triassic to Early Jurassic floras of East Asia, but, it generally occurs both in the DanaeopsisSymopteris and Dictyophyllum-Clathropteris Provinces in Late Triassic to Early Jurassic of East Asia (Kimura and Kim, 1984a; Kim, 1993). The former represents a subtropical to temperate climate and the latter a tropical to subtropical climate ( $\mathrm{Li}$ and Zhou, 1979). The fossil flora from the Nampo Group is obviously a members of the DictyophyllumClathropteris Province based on the their floristic composition (Kimura and Kim, 1984a; Kim, 1993). The presences of Czekanowskia and Leptostrobus in the Korean Late Triassic floras indicate that there were some interchanges between the Korean Late Triassic floras and the coeval DictyophyllumClathropteris and Siberian floral Provinces mentioned above during the Late Triassic time. Ash (1994) mentioned that the Czekanowskia leaves were deposited under a humid, temperate to tropical climate based on the presence of leaves in Eurasian coalbearing sequences. This climate condition partly agrees with that of the Daedong flora which might have been flourished under tropical to subtropical climate (Kimura and Kim, 1984a).

As mentioned before, twenty species of Leptostrobus have been reported from the Late Triassic to the Lower Cretaceous floras of the world (Liu et al., 2006). In the Late Triassic floras, Leptostrobus is very rare in occurrence, and only five species of Leptostrobus were known from the Upper Triassic strata of the world as follows: Leptostrobus cf. laxiflora Heer (Oishi and Takahashi, 1936; Oishi, 1940), L. sp. (Jones and De Jersey, 1947), L. sphaericus Wang (Wang and Wang, 1984; Liu et al., 2006), L. cookii Clifford and Camilleri (Clifford and Camilleri, 1998), and Leptostrobus myeongamensis Kim (Kim et al., 2002). Therefore, the occurrence of Leptostrobus myeongamensis Kim from the Late Triassic of Korea is one of the oldest records of the world.

Pant (1957) named Czekanowskiales as an isolated gymnosperm group. Apart from the classical studies, subsequent contributions were made to this order by Harris (1935, 1951), Krassilov (1968, 1970, 1972), Harris and Miller (1974), Samylina and Kiritchkova (1993), and Liu et al. (2006). However, as mentioned by Taylor et al. (2010), even now the affinities of the Czekanowskiales remains problematic.

\section{Conclusion}

A single cone axis and two cone bases were discovered from a single locality of the Upper Triassic Amisan Formation, Nampo Group, Korea. They belong to Leptostrobus myeongamensis Kim based on the their morphological features of cone axis and base. Leptostrobus myeongamensis Kim is closely associated with foliage of Czekanowskia ex gr. rigida Heer. Although, none of them has been found in organic connection with Czekanowskia leaves, it is considered that they belong to the same taxa based on their common occurrence. Leptostrobus species is very rare in occurrence in the Late Triassic floras of the world, only five species of Leptostrobus were known. Therefore, the occurrence of Leptostrobus myeongamensis Kim in the Late Triassic flora of Korea is one of the oldest records of the Mesozoic floras in the world. 


\section{Acknowledgments}

I would like to express my sincere thanks to Professor Jeong Yul Kim of the Korea National University of Educational and Seong Joo Lee of the Kyungbuk National University for their critical reading of the manuscript and valuable suggestions.

\section{References}

Ash, S.R., 1994, First occurrence of Czekanowskia (Gymnospermae, Czekanowskiales) in the United States. Review of Paleobotany and Palynology, 81, 129-140.

Choi, H.I., Shu, H.G., and Kim, D.S., 1986, Depositional environment and basin evolution of the Daedong strata in the western part of the Chungnam Coalfield. Coal Geology Research, Report KR-86-18, Korea Institute of Energy and Resources, Taejon, 45 p. (in Korean with English abstract)

Choi, H.I., Kim, D.S., and Suh, H.G., 1988, Stratigraphy, depositional environment and basin evolution of the Daedong strata in the Chungnam Coalfield. Ministry of Science and Technology, Report KR-87-(B)-3, Korea Institute of Energy and Resources, Taejon, 97 p. (in Korean with English abstract)

Clifford, H.T. and Camilleri, N., 1998, A mature cupule of Leptostrobus (Czekanowskiales) from the Late Triassic of Queensland. Memories of the Queensland Museum, 42, 445-447.

Harris, T.M., 1935, The fossil flora of Scoresby Sound, East Greenland. Part 4. Ginkgoales, Coniferales. Lycopodiales and isolated fructifications. Meddelelser om Grønland, 112, 1-176, pls. 1-29.

Harris, T.M., 1951, The fructification of Czekanowskia and its allies. Philosophy of Transaction, Royal Society, London, (B), 235, 483-508, pls. 18-19.

Harris, T.M. and Miller, J., 1974, Czekanowskiales. In Harris, T.M., Millington, W., and Miller, J. (eds.), The Yorkshire Jurassic flora, IV. British Museum (Natural History), 79-150, pls. 4-8.

Heer, O., 1876, Beitrge zur Jura-flora Ostsibiriens und des Amurlandes. Mmoires Acadmie Impriale Sciences, St.Ptersbourg, Sries 7, 22, 1-122, pls. 1-31.

Heer, O., 1880, Nachtrge zur Jura-flora Sibiriens. Mmoires Acadmie Impriale Sciences, St.-Ptersbourg, Sries 7, 27, 1-34, pls. 1-9.

Jones, O.A. and De Jersey, N.J., 1947, The flora of the Ipswich coal measures. Morphology and floral succession. University of Queensland Papers, 3, 1-88, pls. 110.

Kawasaki, S., 1939, Second addition to the older Meso- zoic plants in Korea. Bulletin of Geological Survey of Chosen (Korea), 4, 1-71, pls. 1-47.

Kim, J.H., 1993, Fossil plants from the Lower Mesozoic Daedong Supergroup in the Korean Peninsula and their phytogeographical and paleogeographical significance in East and Southeast Asia. Ph. D. thesis, Kyushu University, Hukuoka, Japan, 315 p, pls. 1-36.

Kim, J.H., 2001, New fossil plants from the Nampo Group (Lower Mesozoic), Korea. Geosciences Journal, 5, 173180.

Kim, J.H. and Roh, H.S., 2008, Organ fossils of Neocalamites carrerei from the Amisan Formation of the Nampo Group, Korea. Journal of the Korean Earth Science Society, 29, 466-473. (in Korean with English abstract)

Kim, J.H. and Kimura, T. 1988, Lobatannularia nampoensis (Kawasaki) Kawasaki from the Upper Triassic Baegunsa Formation, Nampo Group, Korea. Proceedings of the Japan Academy, Series B, 64, 221-224.

Kim, J.H. and Kimura, T. 1989, Sphenophyllum sp. (Sphenophyllales) newly found from the Upper Triassic Baegunsa Formation, Nampo Group, Korea. Bulletin of Natural Science of Museum, Tokyo, Series 2, 15, 9396.

Kim, J.H., Kim, H.S., Lee, B.J., Kim, J.M., and Lee, H.K., 2002, A new species of Leptostrobus from the Triassic Amisan Formation of the Nampo Group in Korea. Journal of the Korean Earth Science Society, 23, 30-37.

Kimura, T. and Kim, B.K., 1984a, General review on the Daedong flora, Korea. Bulletin of Tokyo Gakugei University, Part. IV, 36, 201-236. (in Japanese with English abstract)

Kimura, T. and Kim, B.K., 1984b, Geological age of the Daedong flora in the Korean Peninsula and its phytogeographical significance in Asia. Proceedings of the Japan Academy, Series B, 60, 337-340.

Kimura, T. and Tsujii, M., 1984, Early Jurassic plants in Japan. Pt. 6. Transactions and Proceedings, Palaeontological Society of Japan, New Series, 133, 265-287, pls. 54-56.

Kobayashi, T., 1975, Upper Triassic estheriids in Thailand and the conchostracan development in Asia in the Mesozoic Era. Geology and Palaeontology of SE-Asia. 16, Tokyo University Press, Japan, 57-90, pl. 7.

Krassilov, V.A., 1968, A new group of Mesozoic Gymnosperms: Czekanowskiales. Transaction Academy of Sciences, USSR, 178, 942-945. (in Russian)

Krassilov, V.A., 1970, Approach to the classification of Mesozoic "Ginkgoalean" plants from Siberia. Palaeobotanist, 18, 12-19, pls. 1-3.

Krassilov, V.A., 1972, Mesozoic flora of the Bureja River (Ginkgoales and Czekanowskiales). Far Eastern Geological Institute, Far Eastern Branch, Academy of Sci- 
ences, USSR, 103 p. (in Russian)

Li, X.X. and Zhou, Z.Y., 1979, New advances of Mesozoic non-marine biostratigraphic researches in China. In Nanjing Institute of Geology and Palaeontology, Academia Sinica (ed.), Advances of the study on biostratigraphy in China, Nanjing, China, 100-110. (in Chinese with English abstract)

Liu, X.Q., Li, C.S., and Wang, Y.F., 2006, Plants of Leptostrobus Heer (Czekanowskiales) from the Early Cretaceous and Late Triassic of China, with discussion of the genus. Journal of Intergrative Plant Biology, 48, 137-147.

Miao, Y.Y., 2003, Discovery of Leptostrobus laxiflora Heer from Middle Jurassic Xishanyao Formation in the Baiyang River of Emin, Xinjiang. Journal of Jilin University, 33, 263-267. (in Chinese with English abstract)

Oishi, S., 1940, The Mesozoic floras of Japan. Journal of Faculty Science, Hokkaido Imperial University, Series. $4,5,123-480$.

Oishi, S. and Takahashi, E., 1936, The Rhaetic plants from Province Nagato. A supplement. Journal of Faculty Science, Hokkaido Imperial University, 3, 113-133.

Pant, D.D., 1957, The classification of gymnospermous plants. Palaeobotanist, 6, 65-70.

Reedman, A.J. and Um, S.H., 1975, Geology of Korea. Korea Institute of Energy and Resources, $139 \mathrm{p}$.

Samylina, V.A., 1967, The Mesozoic flora of the area to the west Kolyma River (the Zyrianka Coal-Basin) 11. Ginkgoales, Coniferales, General Chapter. Palaeobotanica, Leningrad, USSR, 6, 133-175. (in Russian with
English summary)

Samylina, V.A. and Kiritchkova, A.I., 1993, The genus Czekanowskia Heer: Principles of systematics, range in space and time. Review of Palaeobotany and Palynology, 79, 271-284.

Shimamura, S., 1931, Geological Atlas of Chosen (1: 50,000), Cheongyang, Daecheon, Buyeo and Nampo sheets and the explanatory text. Geological Survey of Chosen (Korea), 11 p. (in Japanese and English).

Suh, H.G., Kim, D.S., Park, S.H., Lim, S.B., Jo, M.J., Bae, D.J., Lee, D.Y., Ryu, R. S., Park, J.S., and Chang Y.H., 1980, Four sheets of geological maps of the Seongju area $(1: 10,000)$ and the explanatory text. Korea Institute of Energy and Resources, 42 p. (in Korean with English abstract)

Taylor, T.N. and Taylor, E.L., 1993, The biology and evolution of fossil plants. Prentice Hall, NJ, USA, 982 p.

Taylor, T.N., Taylor, E.L., and Krings, M., 2010, Paleobotany. The biology and evolution of fossil plants. 2nd ed., Academic Press, NY, USA, 1230 p.

Vakhrameev, V.A., 1964, Jurassic and Early Cretaceous of Eurasia and the palaeofloristic provinces of this period. Transactions of Geological Institute, Academy Science, USSR, 102, 1-263. (in Russian)

Wang, Z.Q. and Wang, X.F., 1984, Fossil plants. In Tianjin Institute of Geology and Mineral Resources (ed.), Paleontological Atlas of North China II. Geological Publishing House Beijing, China, 223-302. (in Chinese with English abstract)

Manuscript received: July 13, 2010

Revised manuscript received: August 4, 2010

Manuscript accepted: August 20, 2010 